\title{
EFFECTS OF HUMAN ACTIVITIES IN THE COASTAL ZONE OF LAIZHOU BAY
}

\begin{abstract}
The serious destruction of resources and environment in Laizhou Bay has attracted extensive attention of researchers. This study mainly analysed the changes of fish structure and environment in the coastal zone of Laizhou Bay caused by human activities. By consulting literatures and field measurements, the changes of dominant fish species, coastline and sea water intrusion were analysed. The results showed that dominant fish species in Laizhou Bay change from high-economic species to low-economic species under the influence of human activities, and the coastline erosion was serious, and the area of sea water intrusion was also increasing year by year. It is concluded from the research results that human activities had a significant impact on the structure of fish school and the environment. It is necessary to arrange human activities in an appropriate amount to reduce the overexploitation of resources in order to restore the fishery resources and environment in Laizhou Bay.
\end{abstract}

Keywords: Laizhou Bay, human activities, structure of fish school, dominant species, coastal erosion, seawater intrusion

\section{Introduction}

With the increase of population and the intensification of contradiction between man and land, the intensity of exploitation and utilization of marine resources is increasing. In the coastal zone with abundant resources and convenient transportation, high-intensity human activities have brought a series of negative effects [1]. Lammers et al. [2] studied the Alaotra wetland and pointed out that high-intensity human activities formed new plant communities in the margin of the marsh zone, mainly invasive species, and the water level was seriously reduced. Ruppert et al. [3] simulated the impact of human activities on the Pacific Ocean and found that human activities caused changes in the benthic structure of the coral reef environment, reduced coral coverage and biomass of reef sharks and predators, i.e., affecting the health and function of the ecosystem. Flynn et al. [4] pointed out that the dissolution of human carbon dioxide into seawater caused eutrophication of water, increased the number of phytoplankton, and increased the $\mathrm{pH}$ value of water. Maanan et al. [5] found that human activities could induce the coastal vulnerability caused by sea level rise, studied the coastal vulnerability index along the Mediterranean coast, and found that $54 \%$ of the coastline were moderately vulnerable, $42 \%$ was very vulnerable, and only $4 \%$ was relatively vulnerable. Laizhou Bay coastal zone has abundant natural resources and superior geographical position. Since the 1980s, with the rapid growth of

\footnotetext{
${ }^{1}$ College of Geography and Environment, Shandong Normal University, Jinan, Shandong 250358, China

${ }^{2}$ Institute of Geography and Tourism, Qilu Normal University, Jinan, Shandong 250000, China

*Corresponding author: meih_sdnu@163.com
} 
population and the rapid improvement of economic level, the intensity of human activities has increased, and serious natural disasters have happened [6]. This study analysed the impact of human activities on the structure of fish school and environment in Laizhou Bay. It was found that human activities led to changes in the structure of fish school and degradation of the environment. Reasonable arrangement of human activities is the effective way to improve fishery resources and promote environmental recovery in Laizhou Bay.

\section{Overview of Laizhou Bay}

\section{Natural environment}

Laizhou Bay is the largest bay in Shandong province. It covers an area of $6060 \mathrm{~km}^{2}$. It is located in the south of Bohai Sea and has a latitude of $36^{\circ} 25^{\prime}-37^{\circ} 47^{\prime}$ and a longitude of $118^{\circ} 17^{\prime}-120^{\circ} 44^{\prime}$. It includes eight counties (cities) such as Zhaoyuan, Pingdu, Shouguang and Hanting. The seabed topography is monotonous, the sediment is mainly silt, the shoreline length is $516.78 \mathrm{~km}$, the annual average pressure is $1011.1-1016.5 \mathrm{hPa}$, the annual average temperature is $11.9-12.6{ }^{\circ} \mathrm{C}$, the annual average precipitation is $612.5-660.1 \mathrm{~mm}$, and the topography is high in the south and low in the north. Fresh water from Yellow River, Weihe River and Mihe River flows into Laizhou Bay. The flood season is from June to September. The average surface water temperature is between 11.5 and $12.4{ }^{\circ} \mathrm{C}$. In winter, the water is frozen, and the thickness of ice layer is about $15 \mathrm{~cm}$. The average tidal difference is $0.9 \mathrm{~m}$.

\section{Impact of human activities}

\section{Effects on structure of fish school}

Under the influence of human activities, fish are overexploited all over the world, resulting in the loss of fish habitat [7], the deterioration of species' ecological condition [8], and the sharp decline of fish population [9]. Laizhou Bay has a variety of economic fish, which plays an important role in fishery economy. However, under the influence of human activities and climate change, the biomass of Laizhou Bay has declined significantly, and the quality of dominant species has declined. From the point of view of human activities, under the trend of economic interests, the fishing intensity in Laizhou Bay is increasing. The horsepower in 1998 was 42 times that in 1959. With the development of economy, environmental pollution has become more and more serious. The sewage discharge of Xiaoqing River has exceeded the standard seriously, which has reduced the living environment of fish school and led to the decrease of fishery resources and the change of fish school structure.

\section{Effects on the environment}

This study mainly considers the degradation of coastal erosion and sea water intrusion. Coastal erosion refers to the phenomenon that coastline recedes due to man-made or natural factors, which is a common problem in coastal zones all over the world. For example, Mekong Delta has large-scale coastal erosion and land loss [10], the Kien Giang coast of Vietnam has serious coastal erosion and mangrove degradation [11], and the largest erosion area in the Nile Delta is between 24 and 36 m/a from 1990 to 2014 [12]. Human activities have a significant impact on coastal erosion [13]. The decrease of sediment inflow into the 
sea is one of the reasons [14]. In Laizhou Bay area, the sediment that inflows into rivers such as Xiaoqing River and Mihe River has been dramatically reduced due to the construction of reservoirs and sluices in the upper reaches.

Seawater intrusion is also widespread in the world. It can be seen in the Bohai Sea, North Yellow Sea, Yangtze River Delta and Pearl River Delta in China. The problem of seawater intrusion in Laizhou Bay is very serious, which is inseparable from human activities [15]. In 1980-1989, due to the reduction of rainfall, human excessive exploitation of underground freshwater and the increase of drilling density in coastal plain resulted in the decrease of groundwater level and the formation of cone of depression, and the increasing area of cone of depression provided favourable conditions for seawater intrusion.

\section{Research methods}

\section{Structural analysis of fish school}

The research data were from the fishery bottom trawl survey at 10 stations (Fig. 1) in 1959, 1982, 1993, 2003, 2011 and 2015. Data except for 2015 were obtained from literature [16-20]. $250 \mathrm{~kW}$ pair trawler was used. The height of the net mouth was $6 \mathrm{~m}$, the width was $22.6 \mathrm{~m}$, the circumference were 1740 meshes, the mesh was $63 \mathrm{~mm}$, the trawl speed was 3 knots, and the trawling time was $1 \mathrm{~h}$. The species of the catch were identified and recorded. The weight and quantity of the species were determined by index of relative importance $(I R I)$, and its calculation formula is:

$$
I R I=(N+W) \cdot F
$$

where $N$ stands for the proportion of a particular species in the total species, $W$ stands for the proportion of a particular species in the total weight, and $F$ stands for the frequency of occurrence of a particular species.

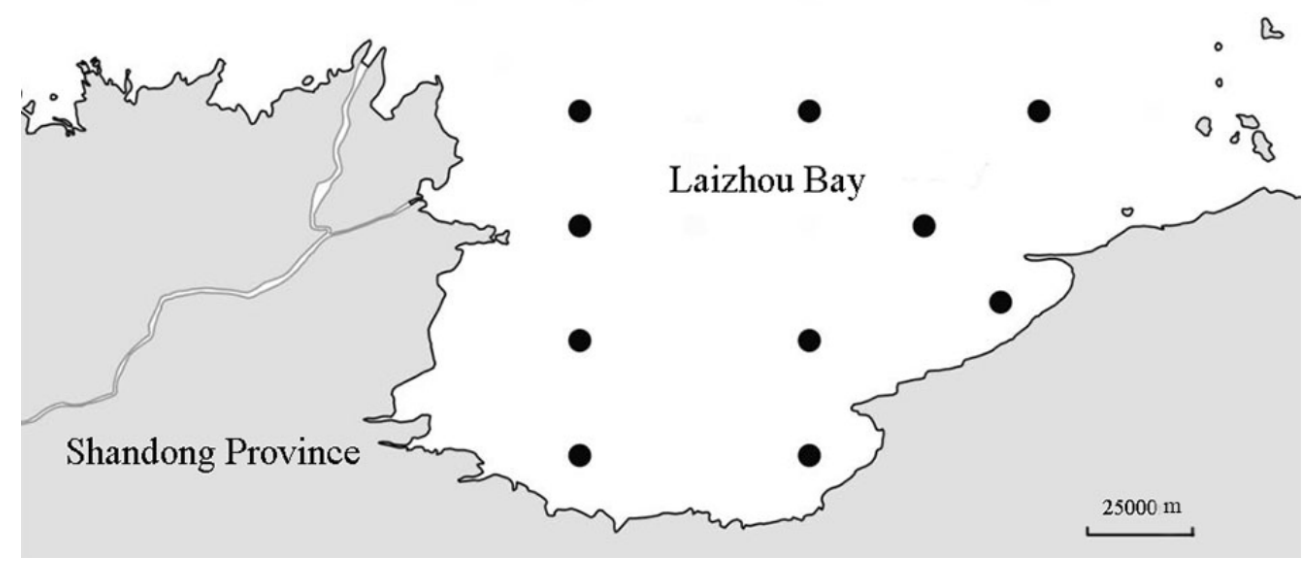

Fig. 1. Location of survey station

The judgement of dominant species is shown in Table 1. 
Judgment method of dominant species

\begin{tabular}{|c|c|c|c|c|}
\hline$I R I$ value & $>500$ & $100-500$ & $10-100$ & $<10$ \\
\hline Judgement result & Dominant species & Important species & Common species & Rare species \\
\hline
\end{tabular}

\section{Environmental impact analysis}

The changes of coastline in Laizhou Bay from 1998 to 2015 were analysed by Digital Shoreline Analysis System (DSAS) [21]. The temporal and spatial changes of coastline were analysed by endpoint change rate. The formula is:

$$
E_{(i, j)}=\frac{d_{j}-d_{i}}{\Delta Y_{(j, i)}}
$$

where $E(i, j)$ stands for endpoint variability of coastline in the farthest and most recent years, $i$ stands for the point at which the coastline intersects the profile line in the farthest year, $j$ stands for the point at which the coastline intersects with the profile line in the most recent year, $d_{i}$ stands for the distance between coastline and baseline in the farthest year, $d_{j}$ stands for the distance between coastline and baseline in the most recent year, and $\Delta Y_{(j, i)}$ stands for the interval between the farthest year and most recent year.

The analysis of sea water intrusion was carried out through historical documents and field measurements.

\section{Research results}

\section{Changes in the structure of fish school}

Between 1959 and 2015, there were 66 species of fish in Laizhou Bay, including Mustelus manazo, Okamejei kenojei, Syngnathus acus, P. argenteus, S. taty, L. polyactis, Pagrus major, Liza haematocheila and so on. In 1982, there were three dominant species in Laizhou Bay, namely E. japonicus (IRI value: 5870.01), S. taty (IRI value: 5438.15) and $N$. albiflora (IRI value: 717.64). In 1993, there were three dominant species, namely E. japonicus (IRI value: 9392.92), T. kammalensis (IRI value: 2067.41) and S. taty (IRI value: 907.76). In 2003, there were four dominant species, namely T. kammalensis (IRI value: 7047.96), S. taty (IRI value: 7039.96$)$, L. polyactis (IRI value: 748.54 ) and $P$. argenteus (IRI value: 619.89). In 2015, there were five dominant species, namely T. kammalensis (IRI value: 7442.51), C. joyneri (IRI value: 1242.11), A. hexanema (IRI value: 852.68$)$, P. fangi (IRI value: 785.9 ) and $S$. taty (IRI value: 717.2).

It can be found that the dominant species of Laizhou Bay in the spring were small economic species such as E. japonicus and S. taty in 1982, important economic species such as $L$. polyactis and $P$. argenteus were also included in 2003 , and the dominant species transformed into demersal fishes such as A. hexanema and P. fangi in 2015.

\section{Interannual variation law of coastline}

The interannual variation law of coastline is shown in Figures 2-4.

It can be found from Figures 2-4 that the coastline of Laizhou Bay showed an overall trend of growth; from the point of view of the maximum erosion of coastline, the erosion of the coastline was the most serious between 1985 and 1995; the maximum erosion rate of Zimai river estuary-Bailang river estuary reached $-51.29 \mathrm{~m} / \mathrm{a}$; in $1995-2005$, the erosion 
rate decreased to $-10.28 \mathrm{~m} / \mathrm{a}$ and increased slightly from 2005 to 2015; from the perspective of interannual change, the growth rate of coastline in Laizhou Bay gradually slowed down. Taking Zimai river estuary-Bailang river estuary as an example, the average variation of the coastline decreased from $154.63 \mathrm{~m} / \mathrm{a}$ in $1985-1995$ to $12.67 \mathrm{~m} / \mathrm{a}$ in 2005-2015.

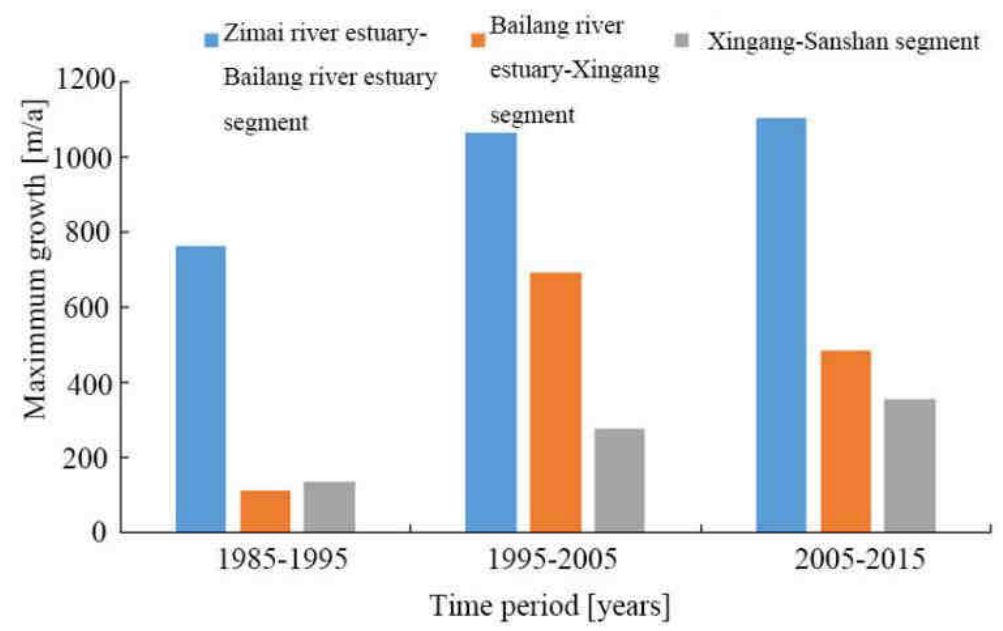

Fig. 2. Maximum coastline growth

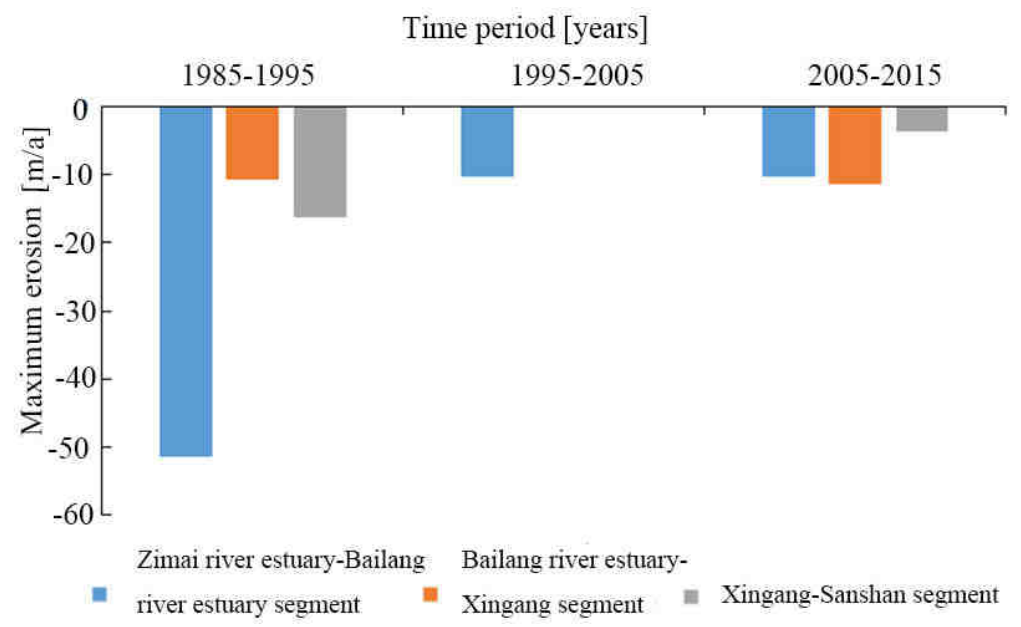

Fig. 3. Maximum coastline erosion 


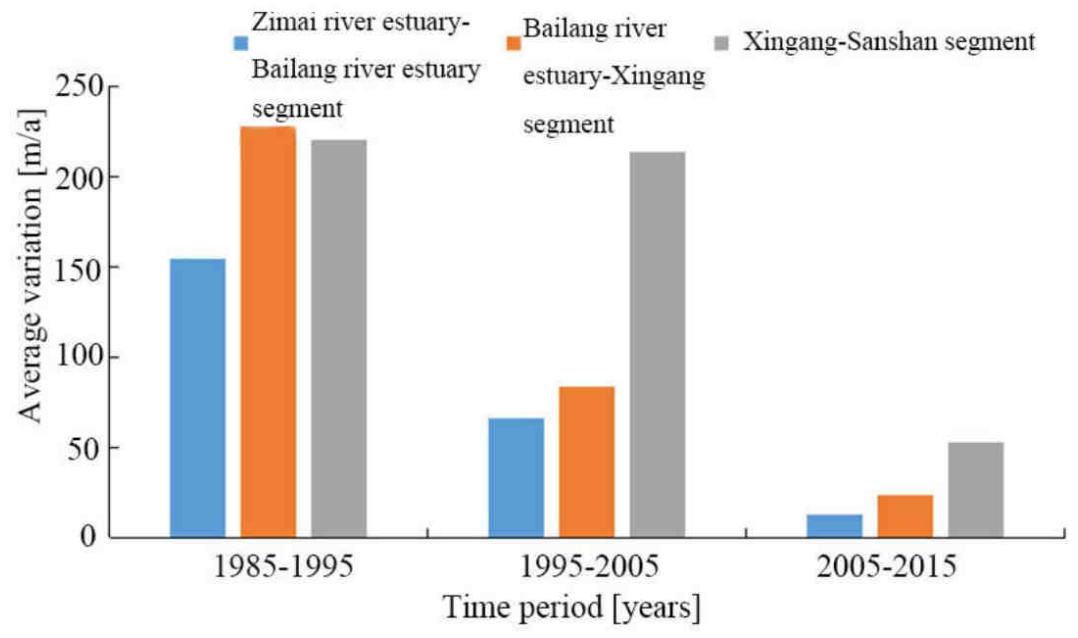

Fig. 4. Average variation of coastline

\section{Seawater intrusion}

Based on historical documents, the process of water intrusion in Laizhou Bay [22] is shown in Figure 5.

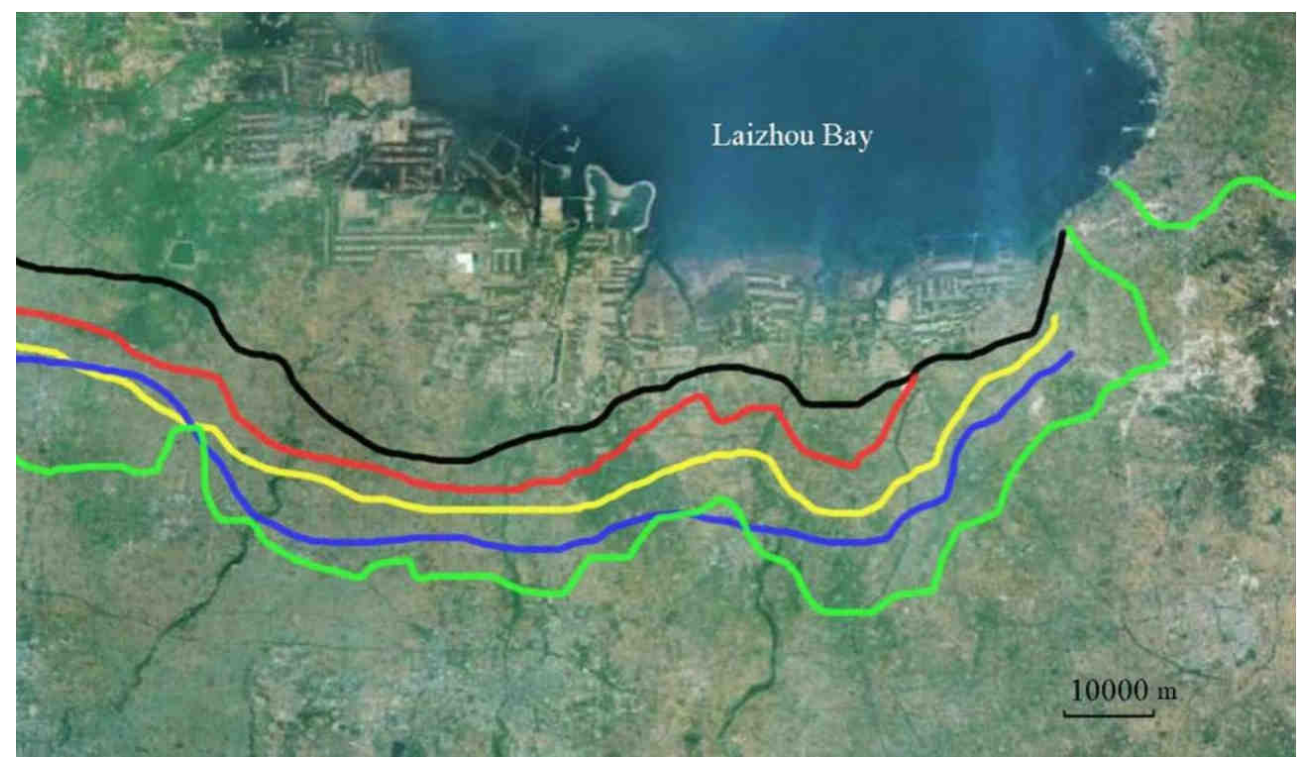

Fig. 5. Seawater intrusion process (black: brine boundary; red: intrusion boundary in 1980; yellow: intrusion boundary in 1989; blue: intrusion boundary in 2000; green: intrusion boundary in 2010)

Figure 5 shows that the area of sea water intrusion in Laizhou Bay was increasing. In the initial stage (before 1980), due to the reduction of rainfall, in order to meet the water 
demand, high-density drilling wells appeared in many areas to obtain groundwater. Therefore, seawater intrusion occurred in these areas. From 1980 to 1989, due to the economic development, the demand for industrial and agricultural water increased further, the phenomenon of groundwater overexploitation was further aggravated, and the seawater intrusion also aggravated. Then, under the influence of climate warming and sea level rise, the area of seawater intrusion was expanding, and the problem of seawater intrusion was still worsening.

\section{Discussion}

Under the influence of human activities, the structure of fish school and environment in Laizhou Bay have changed in varying degrees.

(1) With the improvement of the fishing level of fishing vessels, the fishing intensity of human beings is increasing, which severely damages the fishery resources are seriously and sharply reduces the species and quantity of fish school. Moreover, the marine pollution caused by industrial construction and domestic sewage increases the proportion of nitrogen and phosphorus in the ocean, which catalyses the growth of phytoplankton and promotes jellyfish production. Jellyfish can not be ingested by other advanced species, thus inhibiting the growth of large and medium-sized fish. Offshore pollution also destroys spawning grounds, which further changes the structure of fish school. According to the survey results of dominant species in fish school, it can be found that dominant species transform from large and high-value fish to small and low-value fish, which seriously affects the fishery economy and destroys biodiversity.

(2) Under the influence of human activities, water diversion and sediment regulation in the middle and upper reaches of the Yellow River and reservoir construction in various rivers have reduced the sediment transport to the sea year by year, and the sediment deposition at the estuary has affected the shape of the coastline. In addition, with the rapid development of the coastal zone economy and the progress of port construction, mariculture and other activities, the coastline grow rapidly towards the sea. Development of tourism will also change the coastline. It can be found from Figures 2-4 that the coastline erosion rate of Laizhou Bay was high. Coastal erosion will reduce available land, affect the amount of aquatic resources, and threaten coastal facilities [23], and the accumulation of sediment in estuaries will cause blockage of ports and waterways.

(3) Seawater intrusion is a process of interaction between groundwater and seawater [24], which is a major threat to freshwater resources [25]. Human activities have brought about a serious problem of seawater intrusion [26]. Overexploitation of underground freshwater and brine by human beings has led to a serious decline in groundwater level, destroyed the balance of saltwater and freshwater, made saltwater diffuse to freshwater, and worsened the problem of seawater intrusion. It can be found from Figure 5 that the area of seawater intrusion in Laizhou Bay is increasing year by year, and effective measures are urgently needed.

\section{Conclusion}

This paper mainly studied the impact of human activities on the structure of fish school and the environment. Through literature review and field measurements, it was found that:

1. the dominant species of fish school in Laizhou Bay transformed from large and important economic species to small and low-quality economic species. 
2. Coastal erosion was the most serious in 1985-1995. Although it declined in 1995-2015, it was still a prominent problem.

3. The area of seawater intrusion is increasing year by year, and it is still in a deteriorating state.

Comprehensive experimental results show that human activities have a negative impact on the structure of fish stocks and environmental changes, seriously destroying the resources and environment of Laizhou Bay. Only by reducing human activities properly and vigorously restoring the environment, can the sustainable development of Laizhou Bay be realised.

\section{Acknowledgements}

This study was supported by General Projects of Shandong University Science and Technology Program in 2017: Influencing factors and early warning of coastline changes in Laizhou Bay (J17KA193).

\section{References}

[1] Sudha Rani NNV, Satyanarayana ANV, Bhaskaran PK. Coastal vulnerability assessment studies over India: a review. Nat Hazards. 2015;77:405-28. DOI: 10.1007/s11069-015-1597-X.

[2] Lammers PL, Richter T, Waeber PO, Contreras JM. Lake Alaotra wetlands: how long can Madagascar's most important rice and fish production region withstand the anthropogenic pressure? Madag Conserv Dev. 2015;10:116-27. DOI: 10.4314/mcd.v10i3s.4.

[3] Ruppert JLW, Vigliola L, Kulbicki M, Labrosse P, Fortin MJ, Meekan MG. Human activities as a driver of spatial variation in the trophic structure of fish communities on Pacific coral reefs. Global Change Biol. 2018;24:e67. DOI: 10.1111/gcb.13882.

[4] Flynn KJ, Clark DR, Mitra A, Fabian H, Hansen PJ, Glibert PM, et al. Ocean acidification with (de)eutrophication will alter future phytoplankton growth and succession. Proc Roy Soc London B. 2015;282:20142604. DOI: 10.1098/rspb.2014.2604.

[5] Maanan M, Maanan M, Rueff H, Adouk N, Zourarah B, Rhinane H. Assess the human and environmental vulnerability for coastal hazard by using a multi-criteria decision analysis. Hum Ecol Risk Assess. 2018;1-17. DOI: 10.1080/10807039.2017.1421452.

[6] Gao X, Zhuang W, Chen CTA, Zhang Y. Sediment quality of the SW coastal Laizhou Bay, Bohai Sea, China: A comprehensive assessment based on the analysis of heavy metals. PLoS ONE. 2015;10:e0122190. DOI: 10.1371/journal.pone.0122190.

[7] Heldt KA, Bridges Jr WC, Childress MJ. Behavioral response to habitat loss in juvenile spiny lobsters. Mar Ecol Prog. 2015;521:117-28. DOI: 10.3354/meps11125.

[8] Porcelli A. The tragedy of the commodity: Oceans, fisheries, and aquaculture. Ideas Ecol Evol. 2015;7:86-8. DOI: 10.4033/iee.2014.7.19.e.

[9] Visbeck M. Ocean science research is key for a sustainable future. Nat Commun. 2018;9:690. DOI: 10.1038/s41467-018-03158-3.

[10] Anthony EJ, Brunier G, Besset M, Goichot M, Dussouillez P, Nguyen VL. Linking rapid erosion of the Mekong River delta to human activities. Sci Rep. 2015;5:14745. DOI: 10.1038/srep14745.

[11] Phong NT, Parnell KE, Cottrell A. Human activities and coastal erosion on the Kien Giang coast, Vietnam. J Coast Conserv. 2017;21:967-79. DOI: 10.1007/s11852-017-0566-9.

[12] Ali EM, El-Magd IA. Impact of human interventions and coastal processes along the Nile Delta coast, Egypt during the past twenty-five years. Egypt J Aquat Res. 2016;42:1-10. DOI: 10.1016/j.ejar.2016.01.002.

[13] Freitas JGD, Dias J. A historical view on coastal erosion: The case of Furadouro (Portugal). Environ History. 2017;23(2):217-52. DOI: 10.3197/096734017X14900292921761.

[14] Xu X, Li X, Chen M, Li X, Duan X, Zhu G, Feng Z, Ma Z. Land-ocean-human interactions in intensively developing coastal zone: Demonstration of case studies. Ocean Coast Manage. 2016;133:28-36. DOI: 10.1016/j.ocecoaman.2016.09.006.

[15] Motevalli A, Moradi HR, Javadi S. A comprehensive evaluation of groundwater vulnerability to saltwater up-coning and sea water intrusion in a coastal aquifer (case study: Ghaemshahr-juybar aquifer). J Hydrol. 2018;557:753-73. DOI: 10.1016/j.jhydrol.2017.12.047. 
[16] Jin XS, Deng JY. Variations in community structure of fishery resources and biodiversity in the Laizhou Bay, Shandong. Biodivers Sci. 2000;8:65-72. DOI: 10.3321/j.issn:1005-0094.2000.01.009.

[17] Jin XS. The dynamics of major fishery resources in the Bohai Sea. J Fish Sci China. 2001;7:22-6. DOI: 10.3321/j.issn:1005-8737.2000.04.006.

[18] Jin XS. Long-term changes in fish community structure in the Bohai Sea, China. Estuar Coast Shelf S. 2004;59:163-71. DOI: 10.1016/j.ecss.2003.08.005.

[19] Deng JY, Jin XS. Study on fishery biodiversity and its conservation in Laizhou bay and yellow river estuary. Zool Res. 2000;21:76-82. DOI: 10.3321/j.issn:0254-5853.2000.01.015.

[20] Li XS, Niu MX, Dai FQ. The characteristics of structure and distribution of spawning stock of fishery species in the Bohai Sea. Marine Fish Res. 2008;29:15-21. DOI: 10.1007/s11676-008-0012-9.

[21] Kallepalli A, Kakani NR, James DB, Richardson MA. Digital shoreline analysis system-based change detection along the highly eroding Krishna-Godavari delta front. J Appl Remote Sensing. 2017;11(3):036018. DOI: 10.1117/1.JRS.11.036018.

[22] Available from: https://map.baidu.com/@13332697.284322413,4440538.896906274,11.32z/maptype \%3DB_EARTH_MAP.

[23] Jonah FE, Mensah EA, Edziyie RE, Agbo N, Adjei-Boateng D. Coastal erosion in Ghana: Causes, policies, and management. Coast Manage. 2016;44:116-30. DOI: 10.1080/08920753.2016.1135273.

[24] Zeng X, Dong J, Wang D, Wu J, Zhu X, Xu S, et al. Identifying key factors of the seawater intrusion model of Dagu river basin, Jiaozhou Bay. Environ Res. 2018;165:425-30. DOI: 10.1016/j.envres.2017.10.039.

[25] Badaruddin S, Werner AD, Morgan LK. Water table salinization due to seawater intrusion. Water Resour Res. 2015;51(10):8397-408. DOI: 10.1002/2015wr017098.

[26] Chi Y, Zheng W, Shi H, Sun J, Fu Z. Spatial heterogeneity of estuarine wetland ecosystem health influenced by complex natural and anthropogenic factors. Sci Total Environ. 2018;634:1445-62. DOI: 10.1016/j.scitotenv.2018.04.085. 